\title{
SOCIAL AND POLITICAL IDEAS OF ALDOUS HUXLEY THROUGH BERNARD MARX'S CHARACTER IN BRAVE NEWWORLD
}

\author{
Muh. Haris Zubaidillah \\ Tarbiyah, Sekolah Tinggi Ilmu Alquran (STIQ) Amuntai, Kalimantan Selatan, Indonesia \\ hariszub@gmail.com \\ Desti Daniaty \\ Adab dan Humaniora, UIN Sunan Gunung Djati Bandung, Jawa Barat, Indonesia \\ destidaniaty@gmail.com
}

\begin{abstract}
Social and political ideas have important role and influence in society life. Because, it can change human's thought or mind. In this case, Aldous Huxley as author constructs a character in the novel Brave New World and it is his ideas. He includes his ideas through one of characters in his book. It is seen in character Bernard Marn's feeling, such as; Bernard Marx's feeling as nature of human, Bernard Marx's Feeling to Soma, and Bernard Marx's Feeling to the concept of happy life in The World State. So, the researcher feels a necessity to analyze political ideas of Aldous Huxley through Character Bernard Max in Brave New World. Based on the problem above, the researcher needs to analyze the political ideas of Aldous Huxley through character Bernard Mar in Brave New World by analyzing the character dialogue used the descriptive method. The descriptive method on the research involves a collection of technique used to specify, delineate or describe naturally the occurring of changing characterization without experimental manipulation. The researcher needs to analyze about what are the social and political ideas of Aldous Huxley through the character Bernard Marx constructed in the novel Brave New World. The researcher analyzed it by using Historical Literary Criticism. All the data are taken from the novel Brave New World written by Aldous Huxley. The analysis of data deals with the descriptions social and political ideas of Aldous Huxley through the character Bernard Marx constructed in Brave New World containing: Bernard Mary's feeling as nature of human Bernard Marx's Feeling to Soma, and Bernard Man's Feeling to the concept of happy life in The World State. The literary work is very dominant to socialized ideas, opinion, and massage as values to the society. Therefore, it has great influences to deliver values to the society through the reader. So, it can be concluded that author has power of his work and can include his ideas, opinion, and massage also values in his work as like Aldous Huxley. Then, political ideas of Aldous Huxley throngh character Bernard Marx in Brave New World are author's politic (Aldous Huxley), be attempted to express his ideas in a work.
\end{abstract}

Keywords: social, political, ideas, Aldous Huxley, Bernard Marx, Brave New World.

DOI:

\section{INTRODUCTION}

Human life from time to time always changes. Many discoveries of scientists are very useful for a run of human life. A civilization of the world also changes, more progress and develops. However, all of the things have good impact and bad impact or there are positive side and negative side for all people. The positive impact is that civilization of human in this over ground more progresses and develops. With there is technology all of the things will be easy and fast. Whereas the negative impact, the civilization of human is far with their prestige as human, they don't appear as personal themselves and appear many of differences. Thereby, the civilization of human's problems more complex.

Development of technology changed the civilization of human beings and their ways of thinking. Some people are happy with that progression because they are overside. Whereas some people else are unhappy because they are beneath the side. Finally, they fantasize this world as together ownership and all of the things is together ownership, as in the novelBrave New World, "Everyone belongs to everyone else" (Huxley, 1994: 38) There is not different each one and other. If it is like this, 
those both opinions break the truth human prestige.

Therefore, one of the thinkers or authors Aldous Huxley gives his thought about that opinion, in order to human's ways of thinking back to their nature as the human in his work Brave New World

Civilizations of human consist of several societies and societies consist of several individuals. If something happens to one of them, everyone will feel it all Huxley in his work depicts where a state there is no difference and disagreement.

All of the people are happy because there is no again own private or ownership, but everyone belongs to everyone else or belongs to society Human life was built by Huxley in his work is so contradiction to the truth of human life. Aristoteles (Gatara, 2008: 37) states "Human is the rational creature that has free will" And human beings have no same talent, perspicacity, and ability" (Plato in Gatara, 2008: 37). Therefore, mankind has to get the opportunity to improve appropriate with their skill and ideas (Budiardjo, 2004: 120). He has done this thing to give a description of how the second opinion is that they wish to be happen, it is Marxism or communist's ideology "There is no own private again on production tools" (Poepowardojo, 1989: 171) In addition, he gives the descriptions of political society in his work, he also inserts ideas. "Idea is the plan, though, or suggestion for a possible course of action" (Longman, 2003:204). Then, the idea is very important in all of the things. Its role is revealed by him in his work indirectly that can influence human life or people's opinion.

The idea is a plan of life that is so played role. Likewise, ideas are in the novel Brave New World. The ideas offered by Huxley are latent and political because they refer to many of human life. Gatara (2008: 25) states 'Politic is art that refers the politic is ability and skillfulness entirely from someone that wants to create creative power (idea), taste, and wish." Whereas, according to Easton (Budiardjo, 2004: 13)'Politic is the study of the making of public policy. Political ideas are offered by Huxley is inserted in character in his work Brave New World. The character is one kind of fiction elements which has an important role in an event or deed of story. As like Keraf (2004: 157) states about the character "Character is one of the factors that must count in a deed" Whereas, according to Beaty (1973:102) "Character is someone who acts, appears, or is referred to as playing a part in a literary work."

With his social and political ideas, Huxley wishes all of people or readers following his thought on the civilization of the world. Indirectly, Huxley persuades wish all of the people. Keraf (2004: 118) states 'Persuasion is an art of verbal that means to make convincing someone in order to do something that wished by speakers in this time or in the future." "And because the final destination is in order to readers or hearers to do something, then persuasion also can consist in ways to make the decision. They receive the persuasion have to get the conviction, that decision is made is the right and wise decision and did without compulsion" (Keraf, 2004: 118).

So, it is one way to believe in what he told, expressed, though, and desired. An author within a story or his work certainly has full authority toward his work and that authority can make or string up word of his at will. Budiardjo states about power, "Power or authority is someone's ability or a group to influence people's role or other groups appropriate with doer's hope”. Then, Huxley has full authority toward his work. And it is not wrong if one of the elements in his work is character become an influence to all of the people. With this authority, Huxley has full power to express or explore "ideas" in his work. the politic medium which he wants to say even.

The problems above are related to historical critique. Then, this paper used a historical approach, because this paper analyzed political ideas of author Aldous Huxley. And it can do with one of the kinds of novel characters. The character in the novel Brave New World was Bernard Marx and he becomes a social and political instrument constructed by the author; Huxley. He told it directly or 
indirectly through his work. So, a character can be a social or political idea of the author, because the author has full authority for his work as Aldous Huxley Based on the background of the problem above, entitled "Social and Political Ideas of Aldous Huxley through Bernard Marx Character in Brave New World'.

Based on the background of research above, it can be formulated into the two research question: What are the social and political ideas of Aldous Huxley through the character of Bernard Marx constructed in the novel Brave New World?

\section{SOCIAL AND POLITICAL IDEAS}

All social science is studying human as a member of the group. The appearing those groups are because two characters of human contradict each one and each other, each one side they want to compromise and each other disposed to compete with fellow being (Budiardjo, 2004: 32).

And Budiardjo also (2004: 33) states "Human has instinct life for a companion, life for together with the other people communally. Every human has physical requirement although mental that is difficult to full it by singlehanded." Human needs to eat, drink, family, and move safely, and others. To fulfill the necessities and importance, it makes relationships and cooperation with the other people with organizing kind of groups and association, especially with a family (Budiardjo, 2004: 33).

Lasswell (Budiardjo, 2004: 33) states In a life of groups and in the relation with the other human, basically every human needs several values and they are power, education, wealth, well-being, skill, affection, rectitude \& justice, and respect.

Human is a social creature. Harold J. Laski from School of Economics and Political Science London (Budiardjo, 2004: 33) formulates 'Society means a relation or a society is a group of human beings living together and working together for the satisfaction of their mutual wants.”
And to full fill, human's or society's necessities and importance are needed a tool to control or organize it. It isn't it, they will vie wholly independently dateless and appearing many conflicts. For that, they need an effective tool to save their run of life and to fulfill their politic. The effective tool to control this trouble is the association of group and the important association in society is a state. The state is an association of human need. Laski (Budiardjo, 2004: 38) states, The State is an agency or authority managing or controlling these (common) affairs on behalf of and in the name of the community Then, the state is a tool or an agency to managing or controlling human relationship and problems in society or community. And it is also the main organization of politic power. So, political society is a tool or agency for managing or controlling run of social life to live well, peace, safety, and wisdom.

Politic according to development Greece period and Rumawi, politic as called "art polica", "politike techne", and "politike episteme (Gatara, 2009: 25).

Means above, politic as art refer that political science is only somebody's ability and skillfulness to create idea, sense, and wish that is owned by pertinent in all of the task and the function of politic (Gatara, 2009: 25), And according to philosopher; Plato (Gatara, 2009: 37 ) is respected in this period throughout that had given the fundamental concept. 'It's being basic political philosophy (thought): righteousness is knowledge: human hasn't the same talent, perspicacity, and ability: State is a nature institute, and the function of political society is collective goodness.'Whereas according to Aristoteles (Gatara, 2009 37) Politic is human as rational creature that has free will, politic is practice science; there is moral role universal that must be obedient by all of the humanity, and State is nature institute.' Then politic is art refer that politic is only somebody's ability and skillfulness to create the idea, sense, and wish that is referred to values, moral, general wisdom, and others.

Literally, ideology is from idea and logos. The idea is conceived and logos is science. 
Then, the simple meaning is a study about the concept. On the base, ideology is formulation from the idea that is an approach to understand how the ideas self is shaped. So that, formulation ideas are used by people as manner or way for their life Gatara, 2009: 168).

Ideology in terminology is defined as a belief system that holds values and ideas organize neatly as basic philosophy, science, social program economic politic being the view of life, the role of thinks, feels, and individual or group act. Meanwhile, Adams (Gatara, 2009: 168) 'put the term ideology more to the framework of politic movement. Its mean here more as the doctrine that is guided political action, idealism must be convinced as political "faith", the destination must be reached, the reason must be straggled, and the vision of ideal society that could be created.

And Zainuddin (Gatara, 2009:69) states 'political ideas close relationship with history and political philosophy, and many things about values, norm, ethics morality, and political idealism.'Generally, political ideas in the operational is manifestation from obsession, intellectual potential, and political socialization, and the representation of reality social sphere with the central attention about state, society, and power (Zainuddin, in Gatara, 2009:69).

Gatara concludes (2009:71) three variables concept of political ideas that study about political ideas a character or author from some thinkers.

The first variable is a biographical sketch of the thinker (author) as a factor must influence all of his thought or ideas. And the factors of biography are (1) sphere of family and education, (2) business activities and the importance of organization group, (3) closeness with political activities or political party, and (4) political obsession and amount of his works. The second variable is the important themes that being his attention focus on the thinker (author) and the argumentative reasons why that could be his attention. The third variable is political action or political participation of thinker. Many of political thinkers he not only gives ideal ideas but directly also try to mix up with political constellation practices.

Then, political ideas or political ideology is a compilation of values, ideas, norms, belief, and conviction that must be struggled, also must be created. This thing is a thing that used people as manner or way for their life. And to analyze political ideas of character or author follow with several variables above, they are: firstly, biographical sketch of thinker (author) as factor must influence all of his thought or ideas (Sphere of family and education, business activities and the importance of organization group, closeness with political activities or political party, political obsession and amount of his works). Secondly, is the important themes that being his attention focus on the thinker (author) and the argumentative reasons why that could be his attention. And the last is his/her political action or political participation of thinker. Thereby, the writer will know what are political ideas of Huxley which is object research of this paper.

\section{HUMAN RIGHT}

Budiardjo (2004: 120) states "Human right or human prestige is the human's right that is gotten and brought together with his or her born in social life. It reputed that some right which they have without differ base on nation, race, religion, or sex, and it's because fundamental characteristic also universal Base on all of fundamental right is human to have to get the opportunity to improve appropriate with their skill and ideas (Budiardjo, 2004: 120).

Human Right experienced development from one period to other periods, finally defined some human right that holds in a treaty of civil right, and politic and a treaty of economic, social, and culture right. Both manuscripts of treaty begin with the same article sound and may be reputed as a base from all of human right is:

All peoples have the right of selfdetermination. By virtue of that right, they freely determine their political status and freely pursue they're economic, social, and cultural 
development (Budiardjo, 2004: 126). Then, the truth of politic right has the character to protect the individual toward abuse of power by partly of the ruler. There are details of two manuscripts as below:

1. Civil and politic rights including are: right to life (article: 6), right to liberty and security of person (article: 9), right to equality before the courts and tribunals (article: 14), right to freedom of thought, conscience and religion (article: 18) without interference (article: 19), right to peaceful assembly (article: 21), and right to freedom of association (article: 22) right to hold opinions (Budiardjo, 2004: 126)

2. Economic, social, and culture rights including are: right to work (article: 6), right to form trade unions (article: 8), right to social security (article: 9), right to an adequate standard of living for himself and his family, including adequate, clothing and housing (article: 11), and right to education (article: 13).(Budiardjo 2004: 126-127).

In addition, human has three of freedom as their prestige of human. They are freedom of physic, freedom of will/desire, and freedom of moral. Freedom of physic means there isn't force toward their possibilities to move their body. Freedom of will means freedom to desire something. The range of Freedom of will is as far as possible range of thought, and because a human can think everything and also desire everything. And the last freedom of moral means there isn't kind of threats, compressions, prohibitions, and others (Magnis, 1975: 47-49).

Basically, the human had had a human right that is gotten and brought together with his or her born in social life. And human had had several absolute human rights universally without differ base on nation, race, religion, and sex. Base on all of the fundamental right is human may get the opportunity to improve appropriate with their skill and ideas. Beside it, there are two manuscripts of treaty begin with the same article sound and may be reputed as the base from all of the human rights are All peoples have the right of self-determination. By virtue of that right, they freely determine their political status and freely pursue their economic, social, and cultural development. Then, the truth of politic right has the character to protect the individual toward abuse of power by partly of the ruler. If those rights contravened or misused, they have contravened of human rights. As like in novel Brave New World, many of misapplication and infraction of human rights.

\section{COMMUNISM'S IDEOLOGY}

Marxism began with Karl Marx, the nineteenthcentury German philosopher best known for The Communist Manifesto and Das Capital.

And Marx's analysis of society was set forth through his economic station of history; the production of the goods and services that support human life, the exchange of those goods and service, are the bases of all social processes and institutions. Marx does not claim that the economic factor is the only one that goes into, the foundation upon which is the superstructure of nature, law, and government, buttressed by corresponding political;, social, enterprise cult religious, literary, and artistic ideologies In a general way, Marx describes the relations between men's material conditions of life and their ideas by saying that 'it is not the consciousness of air existence, but, on the contrary, it is their social men which determine the existence which determines their consciousness" (Ebenstein, 1965: 4-5).

According to Marx, only public ownership of the means of production can bring into existence a new system of productive relations common use rather than for private profit that will match the tremendous forces of production actually or potentially known to man. In other words, man's capacity to produce will find full expression only in a social system in which production is limited by scarce resources and incomplete knowledge, and not by such faulty social institutions as production for private profit based on the private ownership of the means of production (Ebenstein, 1965: 9).

Then, because of these problems Marx or communist erected this view on ideology for social welfare or many people life. Where the world or the society there isn't again different of 
class and there isn't again own private in production tools. And all of the things be every one belongs to everyone else. So, there isn't cal oppression and misery.

\section{SHORT DESCRIPTIONS OF ALDOUS HUXLEY AND BRAVE NEW WORLD}

Aldous Huxley was born on 26 July 1894, near Godalming in Surrey England. He was born into a family which had only recently become synonymous with the intellectual aristocracy. So, he was sent to preparatory schools for highclass children and eventually made his way to the very reputable private school, Eton at age thirteen. His father, Leonard Huxley, taught and later worked and wrote for a publishing firm, and his mother, Julia Frances Arnold Huxley, founded a girls school.

Like all the sons of his family, Huxley attended Eton, a prestigious preparatory school, and Balliol College, Oxford. His education, then, represented a privileged road to power for wealthy and well-born British men who sometimes displayed real brilliance. Huxley was among the best of them, certainly. The poor sight caused by the eye disease prevented the pursuit of his first career choice, medicine, but he threw himself into a study of literature, reading with the help of a magnifying glass. In 1915, Huxley took a First (highest honors) in English Literature.

A less formal, but nonetheless an important part of Huxley's education was his regular attendance at Lady Ottoline Morrell's gettogethers, which provided many literary, artistic, and political reformers and experimenters the chance to meet and talk. Here Huxley met novelist Virginia Woolf, economist John Maynard Keynes, and critics Bertrand Russell and Clive Bell-some of the most important writers and thinkers of the time. Huxley's early exposure to the ideas of such a diverse and progressive group deeply influenced his worldview and his writing.

Huxley won the James Tait Black Memorial Prize for Fiction from the University of Edinburgh in 1939 for his novel After Many a
Summer Dies the Swan. In 1959, he received the Award of Merit and Gold Medal from the American Academy and Institute of Arts and Letters and accepted an honorary Doctor of Letters degree from the University of California. The year before his death, he received the Companion of Literature from the British Royal Society of Literature.

Huxley died of cancer at this home in Hollywood on 22 November 1963 unaware that President J. F. Kennedy had been assassinated earlier that afternoon in Dallas. In 1971 his ashes were returned to England and interred in his parents grave at Compton in Surrey.

Brave New World is one of the principal dystopian or anti-stop ls media catchphrase, viewed as ultra- in a novel of the twentieth century. Its title is now a pervasive automatically invoked in connection with any development $\mathrm{v}$ modern, ineffably zany or involving a potential threat to human liberty. When Huxley wrote the novel, however, he had other things on his mind besides the nightmarish' future, and a knowledge of the precise circuit conception and composition can help us to explain the ambivalence which so many readers have sensed in Brave New World. And not only that, Brave New World described paradoxically, it is the anxieties and uncertainties which beset Britain and Huxley in 1931, and which resulted in the rich ambivalence of his novel, which has guaranteed Brave New World's status as a twentieth-century classic.

It was The Wall Street crash of October 1929 triggered a global depression which had severe repercussions for those areas of Britain which depended exclusively on the staple industries. Unemployment rose rapidly in these regions during the next two years, a and the early months of 1931, with the country's economic problems growing daily more acute and parliament increasingly exposes as an ineffectual bystander. Britain appeared to be on the brink of chaos. Many commentators predicted that the whole of Europe was heading for complete economic collapse and bloody unrest. Civilization itself seemed doomed. 


\section{METHODOLOGY}

This research used a descriptive method that refers to the analysis of this about political ideas. According to Nawawi (1988:63) 'Descriptive method is able means as procedure cleavage of problems are researched by describing defining subject or object condition of research (someone, institute, society, and etc.) in the present grounded on facts that appear or as they are." And the destination of descriptive research Suryabrata (1997: 18) states "To make the description in a systematic manner, factual, and accurate about the facts and characteristics of a population or certain territory."

And Abrams (1985: 40-41) divided the literary approach into four kinds. The first is a mimetic approach that views the literary works as an imitation or reflection or representation of the world and human life. The second is a pragmatic approach that views the work as something which is constructed in order to achieve certain effects on the audiences. The third, expressive approach treats a literary work primary in relation to its author. The last is an objective approach that approaches a work of literature as something which stands free form what is often called 'extrinsic reference'.

The last one, objective approach is the approach used in this research. The researcher used this approach to analyze the political ideas from its structure because literature stands for itself. Therefore, the method that is used in this research is structural analysis method. And it means that here the researcher will describe and analyze the facts of the problem which suitable object of this research.

In this matter, the researcher tried to apply this method in analyzing data found in Aldous Huxley's work; Brave New World. And this research also used a historical approach, because it analyzed social and political ideas of Aldous Huxley through character Bernard Marx.

Data of this research are all of the problem's projection related to the theory And the data are the texts of the novel where political ideas and political society stood. All of these data are taken from Aldous Huxley's novel, entitled Brave New World.

Source of data for this research is taken from the novel Brave New World is published at first in 1932 and republished in 1994 by Aldous Huxley. This novel by Flamingo Modern Classic in London.

The data of this research is collected by the technique of study documentation or library research. According to Moleong (2004: 216), "Document is everything was written or film.....". And also he states, "Document as source data is used to examine, to interpret, and even to predict". (Moleong, 2004: 217).

And in the technique of study documentation or library research in this research, the researcher searched data from the text of the novel Brave New World by Aldous Huxley and everything about Brave New World with the author. While the supporting references are gotten by searching the other texts in the books, dictionaries, internet sources, and etc; that contain the theories that will be used for further analysis.

The technique of analyzing data according to Moleong (2004: 281). "The working of analyzing data is to arrange, to put, to classify, to code, and categorize. And the technique of analyzing data in the novel Brave New World by Aldous Huxley included the following steps as below: (1) Identifying, the researcher identified the data which were collected. The data were collected from the novel text and any sources such as; the work of literature, biography of the author, and literary criticism that have been studied. (2) Coding, the researcher coded every dialogue of the character and the characterization or the narration of the author. It is coded by underlining the sentences even paragraph or page, and also folded it; it means the important lines or the important paragraph that is folded. (3) Selecting, the researcher selected the data which were coded. They were selected to find the theme of this research; they are political ideas and political society. It is selected by choosing data nearer to the theme of the research. (4) Categorizing, the researcher categorized the data which were selected. They 
were categorized to classify the theme of this research; they are political ideas and political society. And it is categorized by deep reading and comprehension. (5) Interpreting, the researcher interpreted the data which were categorized. The data needs to be interpreted before analyzing. And the researcher interpreted the data connected with this research based on the assumption and theory. (6) Analyzing, the researcher analyzed the data which were categorized and interpreted. It is analyzed the problem based on historical theory because it analyzed the political ideas of the author, Aldous Huxley. (7) Synthesizing, the researcher synthesized the data analysis based on the results of this research.

\section{RESULT AND DISCUSSION:}

SOCIAL AND POLITICAL IDEAS OF ALDOUS HUXLEY THROUGH BERNARD MARX'S CHARACTER IN BRAVE NEW WORLD

\section{Bernard Max's Feeling as Nature of Human}

The human is a rational creature that has a will. And basically, the human hasn't the same talent, perspicacity, free and ability fore, they have to get the opportunity to improve appropriate with their skill and ideas. Because of all the people have the right of self-determination. As Budiardjo (2004: 120) states, "Human right that is gotten and brought together with his or her born in social life." And if there is mistake or deviationism to human right, then it broke and even disapproved of God's omnipotence or nature.

The explanation above was so obvious how is the truth of human life. It is difference with a life of a character as name Bernard Marx and also the other difference character. Life is determined by caste is. So, every process decanting bottle or baby bottle/box is also different from another caste. After they grow up as child age, they have to study all of the things are determined by controller The World State. Besides it, they also have to follow conditioning in order to control their condition of body, thoughts, and feeling keeps stable. And if they feel unsuitable or their thought disturbed (feeling or high emotion) they take soma directly in order to calm feeling.

A life as above which were been by Bernard Marx all of the people there is in civilization The World State. The life organized beneath controllers and only all of the people happy without less everything. But does not with Bernard Marx, he feels alone and different from the others. His will often different and contradictory with the role there is in the civilization of The World State. So, he has judged the odd man and they think it because there is a mistake in the process of his decanting bottle or bottle/box. The researcher analyzes this is ways or trick of Huxley in a character that opposes the role that is built by themselves. Means he opposes hardly the roles that for the stable of The World State is one o hubby here themselves; he is Bernard Marx.

As a nature of humanity mustn't hold conditioning, but all of the people in The State is controlled by conditioning. So that, it makes Bernard Marx thinks what sense of life if limited with conditioning. He really hates conditioning and feels odd why people that there is in The World State don't feel something as like he feels. Finally, he is the only man that is judged odd by people in civilization in The World State. With that conditioning, Bernard Mank feels all of so limited and to free. This is unreal the true of human life. And he convinces it hard to the of them is Lenina, but her response is far from his hope. instead, Bernard Mar is judged odd and broke orderliness the stability of The World State. All of the people say they happy but is looked by Bernard Marx they are unhappy. They are really unhappy if right they are happy why they have to 0 other people and each limit with their conditioning.

All of the people happy and there aren't people unhappy, because of the stability civilization of The World State conditioned all of the people to have to happy. Mutual sharing and mutual service to each other as call social service. As like slogan or word that often they hear it's "Everyone belongs to everyone else". 
Then, all of the people there are in The World State has a high social soul, but isn't with Bernard Marx. He feels alone, sometimes he wants to alone, and muse or daydreams a thing that thing so contradiction with orderliness the stability of The World State. And Lenina often tries to bring Bernard Marx back to their normal life. But he feels exactly conversely and for it, nobody knows the real his feeling about it. So, "odd man" word that often he gets.

As the nature of human, it stands to reason if Bernard Marx has a feeling to pair with a girl because it was nature and human right to pairs. In the same manner as poured forth in the eleventh article about human right in economic, social, and culture right. It is right to an adequate standard of living for himself and his family, including adequate, clothing and housing (Budiarjo, 2004: 126-127), And in Al-Quran also states (Al-Qur'an Surah An-Naba': 8) "And We create you to be coupled".

Then, a human must get a proper life. And according to constitutively 1945 article: 27, (2), "Every populace of state has right on the job and proper life for humanly (Budiardjo, 2004: 133). And in the declaration of human right, article 25: "Everyone has right on the degree of life that assurance of health or good condition for their selves and their family" (Budiardjo, 2004: 133). Assurance or right as like this never there is in the civilization of The World State. Do not to family life what else have just a girl judged oddly and broke the orderliness the stability of The World State. If they right in couples or sex enough to choose who they want, and then dates her/him or more than it also permitted, because all of the people must be able to give social service. As like words: "Everyone belongs to everyone else", and just do it at all, but no to own, what else to be family life. That thing will break the stability of The World State.

For that thing, Bernard Marx feels there are in a wheel of life The World State, but he can't do anything, because he hasn't powered except only his gaffe feelings to the life of The World State.
And also with human age, there is baby age, child age, teenager age, adult, age and old age. But isn't with The World State. For the stability and happiness of people, there are in The World State, they aren't permitted to old or bad face. Therefore, they give the policy to keep happy and young or good looking, but in sixty old they certain will die, and it is the consequence that they have to receive. So that, not wrong while Lenina looks an old man has changed the shape of her face and she disgusts to look it. Then she takes soma directly to calm her self. After that, Bernard Marx looks there is a woman is giving breast (mother's milk) to her child That view makes him think and his mind begins in disorder. And he braves himself to ask it to Lenina, it is about being a mother, has a baby, and breast the baby, but that question is answered by Lenina's fury because that idea is a forbidding idea and will break orderliness the stability of The World State.

Bernard Marx really disturbed with his feelings, and added again nobody has really understood him and as thought at him. He only judged the odd man and odd man. Until he decides to go to another land, it's different from The World State. It's to the New Mexican Reservation. He wants to look for and finds a different thing is suitable for his mind and heart. Then he goes to ask permission to the Director. Exactly, Director so understands what Bernard Marx's feeling. So, he tells his old story in order to Bemard Mars to cancel his planning. He tells when he walked out with a girl until past over the orderliness the stability of The World State, because that time he didn't bring soma, so he lost his control. And hets on his negligence and folly. He tries to tell the big mistake and its so nasty. Indirectly, he wants to persuade Bernard Marx not to do it, but it's different in Bernard Marx's view toward Director's story, he looks a different thing.

Finally, Bernard Marx and Lenina could see the life in the reservation, it's life is so different from life in The World State. The life there were the children stillborn from their mother's womb, there is marriage, family, culture or habits, there is not conditioning, and etc. As this 
life so different from life in The World State, so they a little rather surprise, but what they look is real. And obvious of the price his embroidery to go to this New Mexican Reservation must be paid with his out case to Iceland because Bernard Marx broke orderliness the stability of The World StateState. Obviously, Director is no joke in this thing and he regrets his folly. Finally, he only could receive Lenina's offering its take soma to calm himself from his high emotion.

Several quotations of Bernard in the book look obviously, how Bernard Marx's reaction toward the system there is in The World State. He doesn't like and oppose it, actually, Benard Marx is one of them. And the reasons just tell if Benard odd man, because there is a mistake when process decanting bottle. And the researcher looks this is only politic or tactic to explain or appear that one of them also disagrees with that system.

Expression or explanation above is a hard critic is given by Huxley toward communism ideology. That criticization is given by Huxley directly to target or the object with constructs the character Bernard Marx. A character and also one of them that is brave to oppose the system itself. Then, the life is dreamed by communism right so unthinkable or unreasonable and even refer to inhumanly, Therefore, Huxley gives his offering social and political ideas constructed through character Bernard Marx and indirectly influences many people's thought.

\section{Bernard Marx's Feeling to Soma}

Soma is a hallucinogen that takes users on enjoyable, hangover-free "vacations", and was developed expressly for this purpose. And soma is one of the ways to control the populace of life in The World State. If their feeling unpleasant or their thought begin to chaos, then in a hurry they take soma. If there is not soma they will suffer. So, soma has the important role feels instability life of The World State, but is not with Bernard Marx. He was unpleasant and so limited with that soma. But every one often orders him to take/drink soma to calm himself.
There is not right choice except taking it and sometimes he really wants to free from it at all, but he can not do anything except fate it. Actually, he wants to struggle the systems there are in The World State, but he can not because they or the system is too big and strong

Finally, he meets with John from Savage. From his discourse with John, he feels a different thing. He feels compatible with John's thought. Walking of life or happiness by his ways without takes soma as like him (Bernard) and people there are in The World State. And he feels this is the true life.

Several quotations in the book look obviously how Bernard Marx's feeling of soma. He so suffers because his life is limited and controlled by soma. But they make more he suffer why all of the people had a hunch that soma could bring them to happiness and composure, whereas which he feels is conversely. He feels his life is limited, bridled or controlled, and he can not expresses himself.

Feeling or characterization of character Bernard Marx is críticization of Huxley. It's about every one dream the condition of the individual, community, and state keep in stable condition. This thing is so difficult to do because the wheel life of the human is keeping on rotating and could change. But they (communist) keep wanting the stable condition, calm, and happy. And Huxley in his book Brave New World criticizes The World State with the ways of control one of them is soma. And right the stability they get but isn't with character Bernard Marx. In fact, one of themselves rejects or opposes it. Then, Huxley criticizes it through one of themselves or someone who is in the same circle with them. Finally, he rejects or opposes it. His expression or flare heart is social and political ideas of Aldous Huxley.

\section{Bernard Marx's Feeling to The Concept of Happy Life.}

Bernard Marx has view self toward the concept of a happy life in The World State, because all of the thing what he feels and the others feel would so different result. As like slogan word 
which often repeatedly that "Everyone belongs to everyone else" a word from one of the elements the concept of happy life World State. Service in order to awake the stability of The World State. But Bernard Marx hates with that word, and his followers is an idiot thing to repeat that word.

Beside it, also celebrate party or social party; they are Ford's Day Celebration, and Community Sings, and Solidarities Service. Where in this ceremony all of the people celebrate of the party, free sex, happy, and peace, but Bernard Marx hates this ceremony/party and he hates everything there are in The World State. But he can not do anything, because they are big and strong.

In the concept of a happy life in The World State, all of the people is keep happy and consider as most conditioned keep together and happy in everything. And unjustifiable or no permitted to alone, bet it is Bemard Man's felt and did. If that feeling comes, so people there are beside him often suggest him to take soma. Whereas Bernard Max wants different thing it is an expectation, but his desirability very contradiction with orderliness the stability of The World State, And when he meets John, he has just fined a thing that he looks for before. It's about the truth of human life.

Finally, Bernard Mark is judged an odd man and also is judged would break the concept of the happy life of The World State. Therefore, the director decides to out case him to Iceland as punishment for lawbreaker and opponent the orderliness the stability of The World State. Where all of the people have to happy with that concept of the happy life, but Bernard Marx instead on the contrary, so he must be lost or go from The World State, because Bernard Marx could be invite or wreak dangerous for the stability of The World State.

From several quotations of Bernard Marx in the book is so obvious how is the reaction or idea of Bernard Marx to the concept of a happy life there is in The World State. Then, the concept of a happy life is made by the controller not absolute make all of the people living happily. For example, is Bernard Marx. Actually, he is also decanting the bottle as kind of them, so why he does not feel as what all of the people in The World State feel. Finally, they only could say it because while the process decanting bottle was being a little mistake. Actually, that isn't a big problem but could be the problem that character, Bernard Marx is a character that constructed by Huxley to criticize or oppose the systems is made by the controller in The World State. Means here, Huxley criticizes or opposes utopia's (communist) desirability. And it is opposed by one of themselves. Then, not only other people but their people self is also opposed it purpose

Aldous Huxley constructed character Bernard Marx as his certain for the prestige it's to pour out many political ideas that are so useful and important human problem; it's to bring back the true human right or prestige human.

\section{CONCLUSION}

Human is a rational creature that has free will. Basically, the human hasn't the same talent, perspicacity, and ability. Therefore, they have to get the opportunity to improve their appropriate skill and ideas, because all peoples have the right of self-determination. And human right that is gotten and brought together with his or her birth in social life. And if there is mistake or deviationism to human right, then it broke and even disapproved of God's omnipotence or nature.

Huxley constructs a character that is social and political ideas in his work. Then, he criticizes through one of the characters there is in the novel, he is Bernard Max. This character very opposes and dislikes the system and all of the things there are in that stability The World State. Actually, Bernard Marx is one of them. Therefore, it should not other people from their selves only opposes or no receive that idea or view, because human is a rational creature that has free will. So Bernard Marx is a an opposer or rejecter their stability system in The World State and he also is been a tool to criticize them. And it is Aldous Huxley social and political 
ideas. He criticizes through rejection of Bernard Marx for their system and Bernard Marx is one of them. Then, uncertain all of people can receive their idea or system, because only one of them rejects it. 


\section{REFERENCES}

Abrams, Meyer Howard. 2000. The Norton Antholog of English Literature: The Victorian Age. New York: Norton \& Company, Inc.

Ahmadi, Abu. 2003. Imu Sosial Dasar. Jakarta: Rineka Cipta.

Beaty, Jerome. Alison Booth. J. Paul Hunter\& Kelly J. Mays. 1973. The Norton Introduction to Literature. America. London: Norton \& Company, Inc.

Booker, M. Keith. A Practical Introduction to literary Theory and Critism. USA: Logman Publisher.

Budiardjo, Miriam. 2004. Dasar-Dasar Ilmu Poitik. Jakarta: Gramedia Pustaka Utama.

Davis, Robert Con\& Ronald Schleifer. 1994. Contemporary Literature Critism; Literary and Cultural Studies. New York \& London: Logman.

Diyanni, Robert. 2002. Literature; Reading Ficton, Poetry, and Drama. America: McGraw Hill.

Duverger, Maurice. 2005. Sosiologi Politik. Jakarta: Raja Grafindo Persada.

Eagleton, Terry. 2006. Teori Sastra, Sebuah Pengantar Komprehensif. Bandung: Jalasutra.

1983. Literary Theory: An introdusction. England: Basil Blackwell.

Ebenstein, William. 1965. Today's Isms: Communom, Fascim, Socialism, Capitatism. USA: Prentice Hal, Inc.

Faruk. 1999. Pengantar Sosiologi Sastra. Yogakara: Pustka Pelajar.

Gatara, Sahid. 2009. Ilmu Politik: Memahami dan Menerapkam. Bandung: Pustaka Setia.

Heraty, Toety. 2000. Hidup Matinya Sang Pengarang. Jakarta: Yayasan Obor Indonesia.

Huxley, Aldous. 1994. Brave New World. London: Flamingo.

Keraf, Gorys. 2004. Argumentast dan Narasi. jakarta: Gramedia.

Kartodirdjo, Sartono. 1992. Pendekatan Ilmu Sosial daiam Metodologi Sejarah. Jakarta: Gramedia Pustaka Utama.

Longman. 2003. Handy Learner's; Dictionary of American English. England: Longman.

Magnis, Franz Von. 1975. Etika Umum: Masalah-Masalab Pokok Filsafat Moral. Jogjakarta: Yayasan Kanisius.

Moleong, Lexy. J. 2006. Metodolog! Penelitian Kualitatif. Bandung: Remaja Rosdakarya.

Mughni, Shafiq. An Anthology of Contemporary Middle Eastern History. Canada: McGill University Montreal.

Nawawi, Hadari. 1998. Metode Penelitian Bidang Sosial. Yogyakarta: Gadjah Mada University Press.

Orford Learner's Pocket Dictionary, 2008. New York: Oxford University Press.

Pickles, Dorothy. 1991. Pengantar IImu Politik. Jakarta: Rineka Cipta.

Poespowardojo, Soerjanto. 1989. Strategi Kebudayaan: Suatu pendekan filosofis. Jakarta: Gramedia.

Ratna, Nyoman Kutha. 2008. Teori, Metodelogi, dan Teknik Penelitian Sastra. Yogyakarta: Pustaka Pelajar.

Roberts, Edgar V. 1964. Writing Theme about Literature. London: Prentice Hall, Inc. 
Samekto. 1998. Ikhtisar Sejarah Bangsa Inggris. Jakarta: Daya Widya \& Gramedia Widiasarana Indonesia.

Siregar, Aminuddin. 1985. Pemikiran Politik dan Perubahan Sosial. Jakarta: Akademika Pressindo.

Standford, Judith A. 2003. Responding to Literature; Stories, Poems, Plays, and Essays: Fourth Edition. America: McGraw Hill Companies.

Suryabrata, Sumadi. 1997. Metodologi Penelitian. Jakarta: Raja Grafindo Persada.

Wahyudi, Ibnu. 1990. Konstelasi Sastra. Jakarta: Usmani (Hiksi)

Wellek, Rene and Austin Warren. 1973. Theory of Literature. USA: Penguin Books.

Zubaidillah, Haris. "Epistemological Views of Islamic Education Philosophy as A Islamic Education Basis.” Al Qalam: Jurnal Ilmiah Keagamaan dan Kemasyarakatan, 2018.

Zubaidillah, Muh Haris. “ANALISIS MATA PELAJARAN FIKIH KELAS X MATERI ZAKAT DAN HIKMAHNYA DI MADRASAH ALIYAH.” Al-Falab: Jurnal Ilmiab Keislaman dan Kemasyarakatan 18, no. 2 (2018): 199-210.

. "HUBUNGAN KEMAMPUAN BAHASA ARAB DENGAN PRESTASI HAFALAN ALQURAN SISWA.” AlMi'yar 1, no. 2 (2018).

—. "MODEL INTEGRATED LEARNING DI TINGKAT SD/MI." DARRIS: Jurnal Pendidikan Madrasah Ibtidaiyah 1, no. 2 (2018).

—. "Nilai-Nilai Pendidikan Adversity Quotient pada Cerita Nabi Musa dalam Alquran." Al Qalam: Jurnal Ilmiah Keagamaan dan Kemasyarakatan, 2018.

——. "PENDIDIKAN ADVERSITY QUOTIENT DALAM KONSEP ISLAM." ADD ABANA: Jurnal Pendidikan Agama Islam 1, no. 2 (2018).

—_. "Sûrah Thâhâ wa mâ tadhammanathu min al-I'lâl wa al-Fawâid at-Tarbawiyyah alIslamiyyah (Dirâsah fî ilm ash-Sharf wa at-Tafsîr)." AlMi’yar 1, no. 1 (2019).

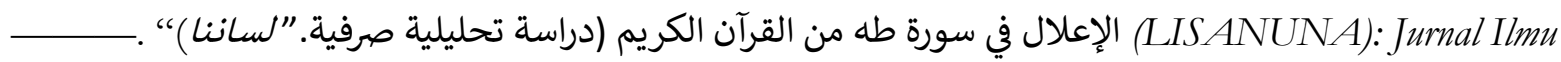
Bahasa Arab dan Pembelajarannya 8, no. 2 (2019): 62-76.

Zubaidillah, Muh Haris, dan Hasan Hasan. "PENGARUH MEDIA KARTU BERGAMBAR (FLASH CARD) TERHADAP PENGUASAAN KOSAKATA BAHASA ARAB.” Al Mijyar 2, no. 1 (2019).

Zubaidillah, Muh Haris, dan M Ahim Sulthan Nuruddaroini. “ANALISIS KARAKTERISTIK MATERI PELAJARAN PENDIDIKAN AGAMA ISLAM DI JENJANG SD, SMP DAN SMA." ADD ABANA: Jurnal Pendidikan Agama Islam 2, no. 1 (2019). 